\title{
NEUROHYPOPHYSIAL HORMONES AND THE EMISSION OF SEMEN IN RABBITS
}

\author{
ANDERS J. AGMO \\ Institute of Zoophysiology, Uppsala University, Box 560, S-751 22 Uppsala, Sweden
}

(Received 31st December 1974)

\begin{abstract}
Summary. To elucidate the importance of the neurohypophysial hormones for the emission of semen, several neurohypophysial peptides were tested in male rabbits and the sperm density in the ejaculates was determined. Besides oxytocin and vasopressin, vasotocin and one oxytocin analogue (de-amino ${ }^{1}$-oxytocin) were used. Only vasopressin, in a dose as low as $10 \mathrm{mU}$, increased the number of spermatozoa in the ejaculates. It is suggested that vasopressin is of physiological significance for the emission of semen, at least in rabbits.
\end{abstract}

\section{INTRODUCTION}

The insertion of the penis in the vagina during coitus, or the sensory stimuli (olfactory, visual or auditory) associated with coitus, causes the release of oxytocin (Debackere, Peeters \& Tuyttens, 1961; Sharma, Fitzpatrick \& Ward, 1972; Barowicz, Wojcik, Ewy \& Wierzchos, 1972) and most probably also vasopressin (Friberg, 1953; Eränkö, Friberg \& Karvonen, 1953; Peeters \& Debackere, 1963; Fitzpatrick, 1966). These two hormones are both known to stimulate contractions in the ductus deferens and ductus epididymidis in the rabbit (Melin, 1970), and oxytocin also has an effect in the ram (Knight, 1972) and the mouse (Hib, 1974). Another effect of these hormones is to increase the volume of semen ejaculated and the sperm density in the ejaculates of rabbits (Kihlström \& Melin, 1963; Kihlström \& Agmo, 1974) and rams (Knight \& Lindsay, 1970), and to increase the rate of transport of spermatozoa through the ductus deferens in rams (Ewy \& Bielański, 1962).

The aim of the present study was to obtain a more complete picture of the importance of the neurohypophysial hormones for the emission of semen. In the study by Kihlström \& Ågmo (1974) in which vasopressin was found to increase the sperm density of the ejaculates of rabbits, lysine-vasopressin was used. Since the neurohypophysial vasopressor principle in rabbits has been identified as arginine-vasopressin (Chauvet, Chauvet \& Acher, 1971), this hormone was used in the present study. Kihlström \& Melin (1963) injected doses of 600 to $1000 \mathrm{mU}$ oxytocin when they studied the oxytocin effects on sperm yield in rabbits. It has since been shown that a dose of $80 \mathrm{mU}$ is maximal with regard to the influence of oxytocin on sperm transport in the uterus in rabbits (Morton, 1974). A lower dose of oxytocin was therefore used in this study. A potent oxytocin analogue, de-amino ${ }^{1}$-oxytocin (ODA 914), was also included. 
Besides these peptides, arginine-vasotocin, the antidiuretic hormone in birds, was also studied. This substance has recently been shown to be present in the pineal gland of the human fetus (Pavel, Dumitur, Klepsh \& Dovcescu, 1973), and the hormone may also have a physiological role in mammals.

\section{MATERIALS AND METHODS}

\section{Animals}

Rabbits of various breeds and weighing 2.9 to $3.2 \mathrm{~kg}$ were housed in individual cages in a room at constant temperature $\left(16\right.$ to $\left.18^{\circ} \mathrm{C}\right)$, and exposed to a $12 \mathrm{hr}$ light $/ 12 \mathrm{hr}$ dark rhythm. Hay and water were freely available, and each animal was given a small amount of rabbit pellets three times a week. Teaser does were ovariectomized 4 weeks before being used. Three days before the experiment started, they were given a subcutaneous injection of $60 \mu \mathrm{g}$ oestradiol benzoate in arachis oil (Ovex B: Leo), and these injections were repeated every 3rd day throughout the experiment.

Table 1. Dosages of peptides injected into male rabbits

\begin{tabular}{lccc}
\hline Peptide & Dose $(m U)$ & No. of animals & No. of observations \\
\hline ODA 914* & 2000 & 5 & 15 \\
Vasopressin $\dagger$ & 10 & 5 & 15 \\
Oxytocin & 200 & 5 & 15 \\
Vasotocinฐ & $50 \uparrow$ & 3 & 15 \\
\hline
\end{tabular}

\footnotetext{
Injections of the peptides were randomly intermingled with injections of saline until fifteen injections of each had been given.

* De-amino ${ }^{1}$-oxytocin, Sandoz.

$\dagger^{8}$ Arginine-vasopressin, Sigma Chemical Co., St. Louis, Mo.

¥ Syntocinon, Sandoz.

\$ Arginine-vasotocin, Sandoz.

T1 1 rat pressor unit corresponds to $0.2 \mu \mathrm{g}$ vasotocin.
}

\section{Procedure}

Males were allocated to four groups, each group receiving either the experimental peptide or saline as a control (see Table 1). Every 2nd day, each rabbit (in randomized order) was injected intravenously with $0.1 \mathrm{ml}$ physiological saline, or a peptide in $0.1 \mathrm{ml}$ saline, until fifteen injections of each treatment had been given. About $30 \mathrm{sec}$ after injection, a teaser doe was introduced and a sample of semen was collected from the artificial vagina. The latency from introduction of the female to the first ejaculation was timed with a stop-watch. The doe was left with the buck and a further ejaculate was collected as soon as the buck mounted for a second time. The volume of the ejaculate was determined to the nearest $0.1 \mathrm{ml}$, and spermatozoa were counted as described by Kihlström \& Fjellström (1967). Any gel in the ejaculates was removed, and not included in the volume of the ejaculate.

Statistical analysis of volume of semen and number of spermatozoa/ejaculate was performed by an analysis of variance with a $n \times 2 \times 2$ design, the factors 
being the number of rabbits $(n)$, treatment (peptide versus saline) and ejaculate (Ejaculate 1 versus Ejaculate 2). Latencies to ejaculation were compared independently for each treatment by the $t$ test.

\section{RESULTS}

None of the peptides injected had any significant effect upon the ejaculate volume (Text-figs $\mathrm{la}$ and $\mathrm{lb}$ ). A significant $(P<0.05)$ difference between rabbits was, however, obtained in the group injected with vasotocin. No significant over-all effect was obtained with regard to number of spermatozoa per ejaculate. A significant $(P<0.01)$ interaction was obtained between treat-

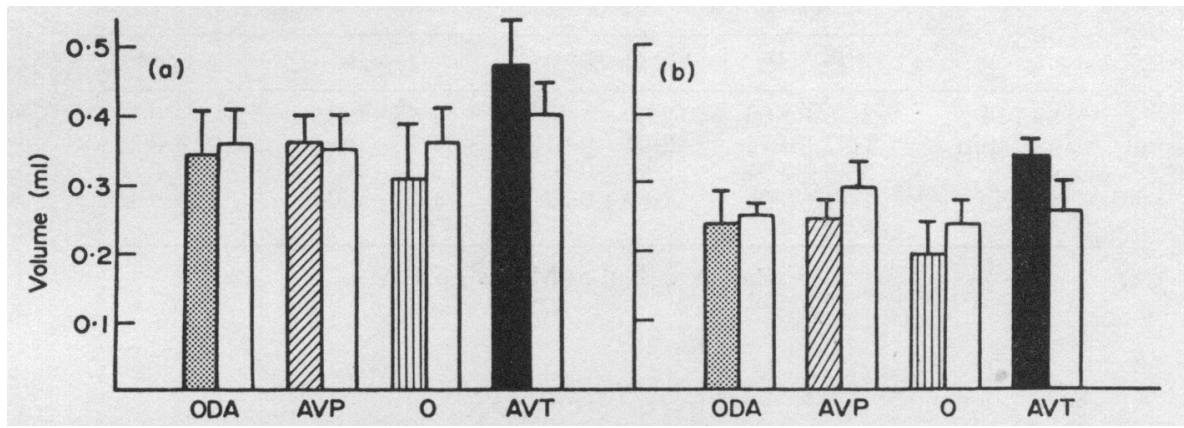

Text-Fig. 1. Volume of (a) Ejaculate 1, and (b) Ejaculate 2 after intravenous injection of various neurohypophysial peptides and one oxytocin analogue or saline. AVP, argininevasopressin, $10 \mathrm{mU}$; AVT, arginine-vasotocin, $50 \mathrm{mU}$; O, oxytocin, $200 \mathrm{mU}$; ODA, ODA $914,2000 \mathrm{mU}$. Open columns indicate control injections with saline. Vertical bars represent \pm S.E.M.

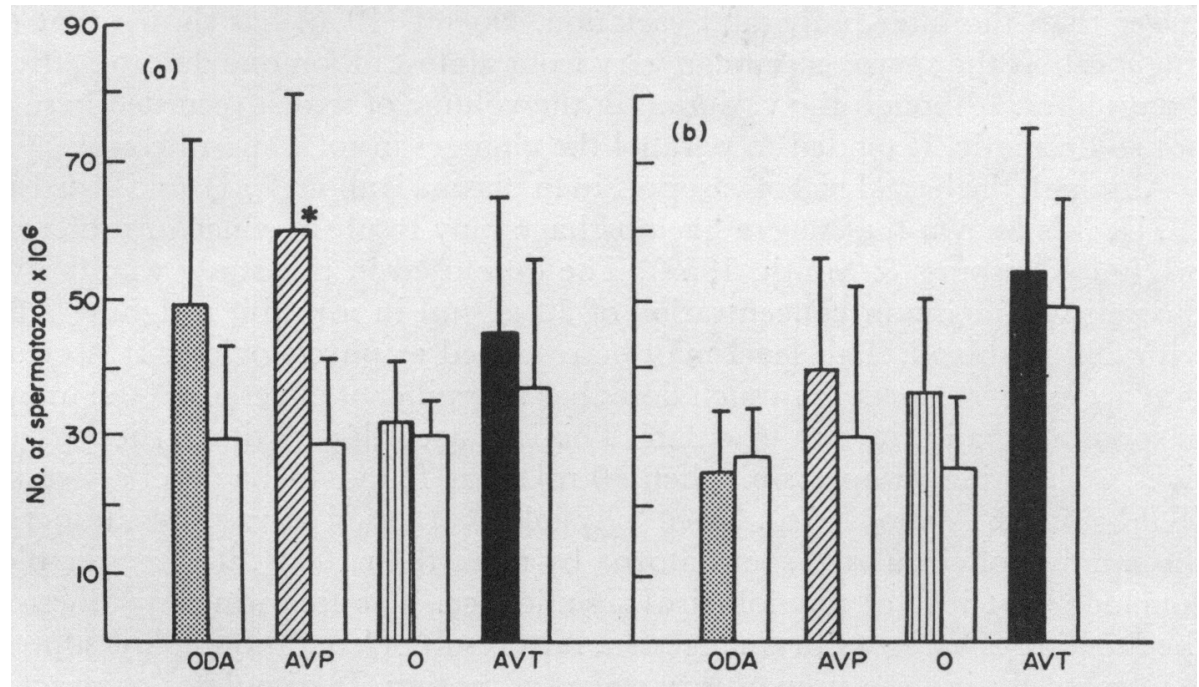

TExT-FIG. 2. Number of spermatozoa in (a) Ejaculate 1, and (b) Fjaculate 2 after intravenous injection of various neurohypophysial peptides and one oxytocin analogue or saline. AVP, arginine-vasopressin, $10 \mathrm{mU}$; AVT, arginine-vasotocin, $50 \mathrm{mU}$; $\mathrm{O}$, oxytocin, $200 \mathrm{mU}$; ODA, ODA $914,2000 \mathrm{mU}$. Open columns indicate control injections with saline. Vertical bars represent \pm S.E.M. * Different from control $(P<0.01)$. 
ment and ejaculate in the bucks injected with vasopressin. A subsequent $t$ test showed that the difference between vasopressin and saline was significant $(P<0.05)$ for the first ejaculate (Text-figs $2 \mathrm{a}$ and $2 \mathrm{~b})$. After oxytocin injection, a significant interaction $(P<0.05)$ between treatment and rabbit was obtained. There were no significant effects of the treatments with regard to latency to ejaculation (Table 2).

Table 2. Latency to first ejaculation and interval between first and second ejaculate in rabbits treated with various neurohypophysial peptides

\begin{tabular}{|c|c|c|c|c|}
\hline & \multicolumn{2}{|c|}{ Latency to Ejaculate 1 (min) } & \multicolumn{2}{|c|}{$\begin{array}{c}\text { Interval between Ejaculates } 1 \text { and } 2 \\
(\text { min })\end{array}$} \\
\hline & Peptide & Control & Peptide & Control \\
\hline $\begin{array}{l}\text { ODA } 914 \\
\text { Vasopressin } \\
\text { Oxytocin } \\
\text { Vasotocin }\end{array}$ & $\begin{array}{l}3 \cdot 15 \pm 1 \cdot 06 \\
2 \cdot 97 \pm 0 \cdot 74 \\
3 \cdot 39 \pm 0.91 \\
1.44 \pm 0.56\end{array}$ & $\begin{array}{l}2.80 \pm 1.00 \\
2 \cdot 61 \pm 0.91 \\
2 \cdot 94 \pm 0.86 \\
1.67 \pm 0.52\end{array}$ & $\begin{array}{l}2 \cdot 67 \pm 0.83 \\
1 \cdot 78 \pm 0.39 \\
2 \cdot 74 \pm 0.77 \\
1 \cdot 77 \pm 0.60\end{array}$ & $\begin{array}{l}2.68 \pm 0.72 \\
2 \cdot 02 \pm 0.52 \\
2 \cdot 28 \pm 0.66 \\
1.29 \pm 0.43\end{array}$ \\
\hline
\end{tabular}

Values expressed as Means \pm S.E.M.

\section{DISCUSSION}

The inter-individual variations in ejaculate characteristics, e.g. volume, sperm concentration, were generally only as large as, or were smaller than, the intra-individual variation. In one instance (the ejaculate volume of the bucks injected with vasopressin), the intra-individual variation turned out to be larger than the inter-individual variation. Dogett (1956) has shown that in a single rabbit the sperm count can vary from almost nil on one day to $320 \times 10^{6}$ 2 days later. Although the variation in the volume of semen recorded here was not so dramatic, it tended to parallel the changes in total sperm count.

Although the basal level of vasopressin in plasma is about $2 \mu \mathrm{U} / \mathrm{ml}$ (Beardwell, 1971), it is known that severe haemorrhage may result in concentrations of 10 $\mathrm{mU} / \mathrm{ml}$ (Ginsburg \& Smith, 1959). The dose used in this study would give a theoretical maximum concentration of $50 \mu \mathrm{U} / \mathrm{ml}$ in a rabbit weighing $3.0 \mathrm{~kg}$ with $200 \mathrm{ml}$ blood. This level may be regarded as physiological. It is evident that arginine-vasopressin in such doses has a significant effect upon the number of spermatozoa in the first ejaculate. This is in accordance with earlier observations with lysine-vasopressin, when $40 \mathrm{mU}$ was found to be an effective dose (Kihlström \& Ågmo, 1974). Since 'physiological doses' of vasopressin increase the number of ejaculated spermatozoa by more than $100 \%$, it is reasonable to conclude that it is of physiological significance. The following hypothesis for the function of vasopressin is suggested. As a result of 'conditioning', vasopressin is released during the preparatory stages of mating. It stimulates contractions of the tubules in the cauda epididymidis and ductus deferens (Melin, 1970), and spermatozoa are transported towards the urethra. When, at ejaculation, the sympathetic discharge induces strong contractions in the ductus deferens, 
the spermatozoa are propelled into the urethra. The term 'conditioning' is here used in its classical sense. The 'unconditioned' stimulus can be the insertion of the penis in the vagina and the 'unconditioned', as well as 'conditioned', response is release of neurohypophysial hormones. The 'conditioned' stimulus may be the odours, sights or sounds produced by the female during courtship and coitus.

At the dose used here, oxytoxin was found to have no over-all effect on the number of spermatozoa ejaculated. Kihlström \& Melin (1963) and Fjellström, Kihlström \& Melin (1968) found an increased number of spermatozoa in the first ejaculate as well as in the combined Ejaculates 2 to 5 , together with an increased sperm density. This is in contrast to the findings in the present study. Fjellström et al. (1968) observed a shortening of the ejaculation latency, whereas no effect was observed in this study. The most likely explanation for the different results is the different doses of oxytocin that were used (about $1000 \mathrm{mU}$ versus $200 \mathrm{mU}$ in this study). Since there was a significant interaction between treatment and rabbit, it is possible that the sensitivity to oxytocin varies between animals and, if the dose used here was a borderline dose, it is reasonable to suppose that it should have effect in some rabbits but not in others. Melin (1970) found that vasopressin $(20 \mathrm{mU} / \mathrm{kg})$ increased the frequency of contractions as well as the tonus in the ductus epididymidis. At the same dose, oxytocin was without effect on these parameters. We suggest, therefore, that the previously observed effects of large doses of oxytocin on sperm yield were pharmacological rather than physiological. Doses above and below the optimal dose described by Morton (1974) had no effect. It could be argued that the failure to obtain effects with oxytocin, ODA 914, and arginine-vasotocin in this study was due to the fact that the doses used were too large, but when other authors have noted effects of oxytocin on ejaculate volume and numbers of spermatozoa (Kihlström \& Melin, 1963, Fjellström et al., 1968), the doses used have been higher than those in this study. In a preliminary experiment, we injected 200 mU ODA 914 with no effect. The dose of vasotocin which had a positive effect was much smaller than the comparable dose of vasopressin (200 mU AVP versus $50 \mathrm{mU}$ pressor activity in the AVT dose) (Kihlström \& Agmo, 1974).

Vasotocin and ODA 914 did not appear to affect the sperm yield. This could indicate that the response to vasopressin is not the result of some nonspecific effects on blood pressure or of a general smooth muscle-stimulating effect. This is indicated by the fact that vasotocin has a vasopressor activity intermediate between that of oxytocin and vasopressin, whereas ODA 914 has a much greater smooth muscle-stimulating activity than oxytocin (Berde \& Boissonnais, 1968).

It is concluded that vasopressin is the neurohypophysial hormone which stimulates the release of spermatozoa. The well-established release of oxytocin during coitus may have other functions affecting male fertility (Melin, 1971a, b).

\section{AGKNOWLEDGMENTS}

The skilful assistance of Miss Siv Hansson is gratefully acknowledged. Syntocinon, ODA 914, and arginine-vasotocin were generously supplied by Sandoz 
AG, Switzerland. This study was made possible by a grant from Längmanska kulturfonden.

\section{REFERENCES}

Barowicz, T., Wojcik, K., EwY, Z. \& Wierzchos, E. (1972) Oxytocic activity measurements in blood plasma of boar during semen collection. Bull. Acad. pol. Sci. Cl. II Ser. Sci. biol. 20, 519-523.

Beardwell, C. G. (1971) Radioummunoassay of arginine-vasopressin in human plasma. 7 . clin. Endocr. 33, 254-260.

Berde, B. \& Boissonnais, R. A. (1968) Basic pharmacological properties of synthetic analogues and homologues of the neurohypophysial hormones. In Handbook of Experimental Pharmacology, vol. 23, pp. 802-870. Ed. B. Berde. Springer, Berlin.

Chauver, J., Chauvet, M. T. \& Acher, R. (1971) Evolution des hormones neurohypophysaires: isolement des principes actifs du lapin et du rat. Biochimie, 53, 1099-1104.

Debackere, M., Peeters, G. \& Tuyttens, N. (1961) Reflex release of an ocytocic hormone by stimulation of genital organs in male and female sheep studied by a cross-circulation technique. $\mathcal{J}$. Endocr. 22, 321-334.

Dogetr, V. C. (1956) Periodicity in the fecundity of male rabbits. Am. F. Physiol. 187, 445-450.

Eränkö, O., Friberg, O. \& Karvonen, M. J. (1953) The effect of the act of copulation on water diuresis in the rat. Acta endocr., Copenh. 12, 197-200.

Ewy, Z. \& BieLANSK, W. (1962) Influence of oxytocin on spermatozoa transport in the ductus deferens of the ram. Proc. 22nd Int. Congr. Physiol. Sci., Leiden, 2, Abstr. No. 545.

Fitzpatrick, R. J. (1966) The neurohypophysis and the male reproductive tract. In The Pituitary Gland, vol. 3, pp. 505-516. Eds. G. W. Harris and B. T. Donovan. Butterworth, London.

Fjellström, D., Kihlström, J. E. \& Melin, P. (1968) The effect of synthetic oxytocin upon seminal characteristics and sexual behaviour in male rabbits. $\mathcal{~ F . ~ R e p r o d . ~ F e r t . ~ 1 7 , ~ 2 0 7 - 2 0 9 . ~}$

Friberg, O. (1953) The antidiuretic effect of coitus in human subjects. Acta endocr., Copenh. 12, $193-196$.

Ginsburg, M. \& Sмiтh, M. W. (1959) The fate of oxytocin in male and female rats. Br. $\mathcal{F}$. Pharmac. Chemother. 14, 327-333.

HrB, J. (1974) The contractility of the cauda epididymidis of the mouse, its spontaneous activity in vitro and the effects of oxytocin. 7. Reprod. Fert. 36, 191-193.

Kinlström, J. E. \& Åcmo, A. (1974) Some effects of vasopressin on sexual behaviour and seminal characteristics in intact and castrated rabbits. F. Endocr. 60, 445-453.

Kinlström, J. E. \& FJellström, D. (1967) Automatic counting of spermatozoa in rabbit semen. $\mathcal{F}$. Reprod. Fert. 14, 155-157.

Kinlström, J. E. \& Melin, P. (1963) The influence of oxytocin upon some seminal characteristics in the rabbit. Acta physiol. scand. 59, 363-369.

KNIGHT, T. W. (1972) In vivo effects of oxytocin on the contractile activity of the cannulated epididymis and vas deferens in rams. 7 . Reprod. Fert. $28,141$.

KNighr, T. W. \& Lindsay, D. R. (1970) Short and long-term effects of oxytocin on quality and quantity of semen from rams. 7 . Reprod. Fert. 21, 523-529.

Melin, P. (1970) Effects in vivo of neurohypophysial hormones on the contractile activity of accessory sex organs in male rabbits. 7. Reprod. Fert. 22, 283-291.

Melin, P. (1971a) Gonadotrophic activity in the pituitary and urine of the male rabbit after oxytocin treatment. Acta endocr., Copenh. 66, 529-539.

Melin, P. (1971b) Spermatogenesis and sperm output in rabbits after long-term treatment with oxytocin. Acta endocr., Copenh. 66, 515-528.

Morton, D. B. (1974) The effect of oxytocin on sperm transport in ovariectomized oestrogen-treated rabbits. 7. Endocr. 61, 139-145.

Pavel, S., Dumitur, I., Klepsh, I. \& Dovcescu, M. (1973) A gonadotrophin inhibiting principle in the pineal in human fetuses. Evidence for its identity with arginine-vasotocin. Neuroendocrinology, $13,41-46$.

Peeters, G. \& Debackere, M. (1963) Influence of massage of the seminal vesicle and ampullae and of coitus on water diuresis of the ram. 7 . Endocr. 26, 449-458.

Sharma, S. C., Fitzpatrick, R. J. \& Ward, W. R. (1972) Coital induced release of oxytocin in the ram. J. Reprod. Fert. 31, 488-489. 